\title{
What Should We Do With Our Solid Tannery Waste?
}

\author{
Shamima Parvin ${ }^{1}$, Lubana Tasnim Mazumder ${ }^{2}$, Shahnoor Hasan ${ }^{2}$, Khondkar \\ Ayaz Rabbani*², Mohammad Lutfor Rahman ${ }^{2}$ \\ ${ }^{1}$ Department of Environmental Sciences, University of Koblenz-Landau, Germany \\ ${ }^{2}$ Department of Environmental Science, School of Environmental Science and Management, Independent \\ University, Bangladesh (IUB), Dhaka, Bangladesh
}

\begin{abstract}
There is worldwide concern about the management of solid waste generated from the tannery industry, primarily because of its chromium toxicity. In many developing countries the solid tannery waste, which is high in protein content, is utilized as animal feed. Recent studies indicate that there is a link between chromium in solid tannery waste, in the animal feed and in the animals themselves. This review examines the toxicity of chromium in solid tannery waste, separately as $\mathrm{Cr}(\mathrm{III})$ and $\mathrm{Cr}(\mathrm{VI})$, and discusses management approaches to control the pollution from solid tannery waste. In order to safely continue using solid tannery waste in animal feed, more emphasis should be placed on the management of Cr(VI) rather than on Cr(III). It is possible to decrease the amount of $\mathrm{Cr}(\mathrm{VI})$ in solid tannery waste by taking proper steps at different stages of the production of leather and feed. This approach is safe, economical and implementable and may be appropriate for countries which are struggling with tannery waste.
\end{abstract}

Keywords:Waste Management; Public Health, Solid Waste; Tannery; Chromium Toxicity; Animal feed

\section{Introduction}

The leather industry is one of the biggest in the world, with an estimated global trade value of more than US\$ 100 billion per year (UNIDO 2010). However, this industry is also considered one of the most polluting industries in the world (WorstPolluted.org 2016). There is considerable use of chemicals and water in the conversion of hides into finished leather product and this generates a large amount of solid and liquid waste (Paul et al. 2013). The amount of solid waste that is generated from tannery processes all over the world is estimated as 6 million tons per year (Rajamani, 2010) The developing world has been the source of more than half of the world supply of leather raw material since 2010 (UNIDO 2010). Solid tannery waste containing inorganic pollutants like $\mathrm{Cd}, \mathrm{Pb}, \mathrm{Cr}$ and $\mathrm{Fe}$ has been reported in countries like Canada (Burbridge et al. 2012), Australia (Avudainayagam et al. 2003), Mexico (Lopez-Luna et al. 2009) Croatia (Famielec and WieczorekCiurowa 2011), India (Gupta and Sinha 2006; Pappu et al. 2007; Sinha et al. 2006), Taiwan (Chuan and Liu 1996), China (Avudainayagam et al. 2003) Saudi Arabia (Sallam et al. 2015) and Bangladesh (Ahmed et al. 2011; Bhuiyan et al. 2011; Kashem and Singh 1999). There are several examples of workplace exposure of chromium in the tannery industry. Chromium was found in the serum and blood of tannery workers in Ontario, Canada which interestingly showed that the chromium levels in the body is not related to the length of employment at the industry but on the amount of exposure to chromium during the day (Randall and Gibson 1987).

China, Vietnam and Brazil are the three giants in terms of leather exports; however they are reported to be shifting their attention away from leather because of rising labor costs (Futurestartup.com 2016). The leather industry in Bangladesh already occupies the second position in the export sector and there are around 270 tanneries in Bangladesh - 90\% of which are located in the Hazaribagh area of the capital, Dhaka (Sharif and Mainuddin 2003; WorstPolluted.org 2016). It is estimated that more than $20,000 \mathrm{~m}^{3}$ of effluent is generated every day in Hazaribagh and the untreated effluent is discharged to a channel leading to the Buriganga River, the main river of Dhaka. Part of the river closest to the effluent discharge points has virtually turned into sewage and it is no wonder that the Blacksmith Institute branded Hazaribagh as $5^{\text {th }}$ among the top ten toxic threats in 2013 (WorstPolluted.org 2016). Very few of the tannery industries in Hazaribagh operate effluent treatment plants because of the high costs associated with the installation and maintenance of suitable effluent treatment plants. Following the publications of Islam et al, (2007), Hossain et al, (2007 \& 2009) and Hossain \& Hasan (2014), local newspapers of Bangladesh made headlines about the ill effects of the consumption of chicken containing large amount of chromium that has come through chrome tanning (Alam 2010). The newspapers recommended not using tannery waste at all for the manufacture of feeds and in fact the law-enforcing authorities went to the extent of destroying some of these feed factories (IRIN ; Star). Recently, the Bangladesh Supreme Court has banned the use of solid tannery waste in the production of poultry feed (Shaon 2016). The Government of Bangladesh has recently started to force the tanneries to shift to a different location where a central effluent treatment plant would be set up for treating the liquid waste before discharge (bdnews24.com 
2016). This is similar to the strategy adopted in countries like Italy where tanneries can only be established in organized industrial districts (Lofrano et al. 2013). This review examines the toxicity of chromium as $\mathrm{Cr}(\mathrm{III})$ and $\mathrm{Cr}(\mathrm{VI})$ in solid tannery waste and suggest management approaches to control pollution from solid tannery waste.

\section{Toxicity Of Chromium}

Chromium exists in several oxidation states, the most common and stable forms in nature is $\mathrm{Cr}(\mathrm{III})$ and $\mathrm{Cr}(\mathrm{VI})$. Trivalent chromium in trace amounts is considered essential for human health while $\mathrm{Cr}(\mathrm{VI})$ is a known carcinogen and is harmful for human health (Table 1).

Table 1: Health effects of $\mathrm{Cr}$ (III) and $\mathrm{Cr}$ (IV)

\begin{tabular}{|c|c|c|}
\hline & $\mathrm{Cr}(\mathrm{III})$ & $\mathrm{Cr}(\mathrm{VI})$ \\
\hline Half-life in human body & 10 hrs (Kerger et al. 1996) & 39 hrs (Kerger et al. 1996) \\
\hline Bioavailability in human body & $0.13 \%$ (Kerger et al. 1996) & $6.9 \% \quad$ (Kerger et al. 1996) \\
\hline Use in human & $\begin{array}{l}\text { Required for the maintenance of normal } \\
\text { glucose, cholesterol and fatty acid } \\
\text { metabolism. (Allowances et al. 1980) }\end{array}$ & No known usefulness \\
\hline Acute health effect & $\begin{array}{l}\text { Shortness of breath, coughing and wheezing } \\
\text { (Grevatt 1998) }\end{array}$ & $\begin{array}{l}\text { Causes strong allergic } \text { reactions; } \\
\text { gastrointestinal effects including abdominal } \\
\text { pain, vomiting and hemorrhage; } \\
\text { neurological effects; dermal exposure } \\
\text { causes skin burns (Goyer and Clarkson } \\
\text { 1996; United Nations Environment } \\
\text { Programme et al. 2015). }\end{array}$ \\
\hline $\begin{array}{l}\text { Chronic effect } \\
\text { (Non-cancerous) }\end{array}$ & No health effect has been reported & $\begin{array}{l}\text { Effects on the respiratory tract; perforations } \\
\text { and ulcerations of the nasal septum, } \\
\text { bronchitis, pneumonia, asthma and nasal } \\
\text { itching; effects liver, kidney, gastrointestinal } \\
\text { and immune systems (Assem and Zhu 2007; } \\
\text { Goyer and Clarkson 1996). }\end{array}$ \\
\hline Reproductive effect & No health effect has been reported & $\begin{array}{l}\text { Possible complications during pregnancy } \\
\text { and childbirth (Costa 1997). }\end{array}$ \\
\hline Cancer risk & $\begin{array}{l}\text { EPA has classified as non-carcinogenic } \\
\text { (Grevatt 1998) }\end{array}$ & $\begin{array}{l}\text { EPA has classified } \mathrm{Cr}(\mathrm{VI}) \text { as carcinogenic } \\
\text { (Grevatt 1998) }\end{array}$ \\
\hline
\end{tabular}

$\mathrm{Cr}$ (III) forms an organic complex called Glucose Tolerance Factor (GTF) that interacts with the pancreatic hormone, insulin, and regulates the uptake of glucose by cells (Barrett et al. 1985). It is essential for lipid, protein and fat metabolism in animals and humans. Chromium deficiency may be responsible for maturityonset diabetes, cardiovascular diseases and nervous system disorders (Grevatt 1998). Unlike $\mathrm{Cr}$ (III), $\mathrm{Cr}$ (VI) has neither any usefulness nor can it be tolerated nearly at as high levels as $\mathrm{Cr}(\mathrm{III})$. Rather, its toxicity is some 5001000 times higher than that of $\mathrm{Cr}$ (III) and it is capable of causing mutation, cancer and cell damage (Costa 1997). Its extreme toxicity is attributed to its easy penetrating ability into cells in the form of negative ions (chromate, dichromate) replacing phosphate and sulfate anions (De Flora et al. 1997). Once inside the cell, $\mathrm{Cr}(\mathrm{VI})$ undergoes step-by-step reduction to $\mathrm{Cr}(\mathrm{III})$. It is these unstable intermediate species such as $\mathrm{Cr}(\mathrm{V})$ and $\mathrm{Cr}(\mathrm{IV})$ that are responsible for causing oxidative damage of lipids and proteins, mutation and cell transformation leading to cancer (Das and Singh 2011). That $\mathrm{Cr}(\mathrm{VI})$ is a human carcinogen has been determined by the National Toxicology Program (NTP), the International Agency for Research on Cancer (IARC), the UK Health Protection Agency, and Office of Environmental Health Hazard Assessment (OEHHA) (Assem and Zhu 2007; Program et al. 2011; Smoke and Smoking 2004). Perhaps the comparison of the toxicity of $\mathrm{Cr}(\mathrm{III})$ and $\mathrm{Cr}(\mathrm{VI})$ would remain incomplete without the mention of the work of Kerger et. al. (Kerger et al. 1996), who had four adult humans ingested with a single dose of $5 \mathrm{mg}$ chromium in $0.5 \mathrm{~L}$ de-ionized water in three chromium mixtures: chromium (III) chloride $\left(\mathrm{CrCl}_{3}\right)$, potassium dichromate reduced with orange juice and pure potassium dichromate. $\mathrm{CrCl}_{3}$ was poorly absorbed (estimated $0.13 \%$ bioavailability) and rapidly eliminated in urine (excretion half-life, about $10 \mathrm{hr}$ ) contrary to potassium dichromate which had the bioavailability of $6.9 \%$ and the half-life, about $39 \mathrm{hr}$. This means that $\mathrm{Cr}(\mathrm{VI})$ has more than 50 times the bioavailability of $\mathrm{Cr}(\mathrm{III})$ and that its half- life is around 4 times longer. If we calculate the average life-time of $\mathrm{Cr}(\mathrm{VI})$, it turns out to be $56 \mathrm{hr}$, about $2 \frac{1}{3}$ days. Thus, if a chicken is on feeds containing $\mathrm{Cr}(\mathrm{VI})$ regularly, there would be bioaccumulation of $\mathrm{Cr}$ (VI), as has been found in our study (Parvin and Rahman 2014). The office of Environmental Health Hazard Assessment (OEHHA) (OEHHA 2010) has derived the value of $8.2 \mu \mathrm{g} /$ day for the Maximum Allowable Dose Level (MADL) for $\mathrm{Cr}(\mathrm{VI})$ by the oral route of exposure. Amongst many studies the office chose the work of Murthy et. al. (Murthy et al. 1996) that found a NOEL (No Observable Effect Level) value of $0.142 \mathrm{mg} / \mathrm{kg}$ body weight-day for female reproductive toxicity in mice. This value was multiplied by 58 to make it applicable for a $58 \mathrm{~kg}$ woman and then divided by 1000 to be on the safe side. 


\section{Management Of Solid Tannery Waste}

Price and Joseph have suggested five strategies for the reduction of the amount of any waste generated from industry (Price and Joseph 2000). They are, in decreasing order of preference - waste minimization, material reuse, material recycling, energy recovery and waste disposal. It is clear from this list that the dumping of waste in a landfill is the least desirable option for waste management. Not only is there a scarcity of suitable land for landfilling in urban areas but there are additional costs involved in the transportation of waste to a landfilling site. Poorly designed landfills also lead to contamination of groundwater by leachates including chromium (Alibardi and Cossu 2016; Ghosh et al. 2012). Methane emanating from landfills also contributes to global warming (Popov 2005; Sekaran et al. 2007). Thermal incineration is a more efficient method for reducing solid waste, but the process produces air pollutants like $\mathrm{SO}_{2}$ and $\mathrm{NOx}$ which need to be removed using air pollution control devices (Kanagaraj et al. 2006; Ping et al. 2008). The ash produced due to thermal incineration is also a source for pollutants like chromium $(\mathrm{Cr})$, halogenated organic compounds and PAHs (Sekaran et al. 2007), Anaerobic digestion of solid is also a suitable method for managing solid tannery waste with the added advantage of producing methane and biogas which can be burnt to produce heat and electricity. The residuals are nutrient rich and can be used as organic manure, although they may contain metal pollutants like chromium. Besides, the process involves high capital costs and low process efficiencies (Sekaran et al. 2007). There have also been extensive research on bioremediation of tannery waste and wastewater which not only has the advantage of using naturally occurring microbes to produce harmless products but is inexpensive compared to thermal or chemical methods (Benazir et al. 2010; Durai and Rajasimman 2011; Gupta et al. 2014; Marzan et al. 2017; Megharaj et al. 2003; Mondaca et al. 2002). The disadvantage of using bioremediation is that the microbes work best at a particular environment and both experience and knowledge is needed for bioremediation to work effectively (Cheung and Gu 2007; Dhal et al. 2013; Rabbani et al. 2015). Vermicomposting of solid tannery waste has been attempted but there is leaching of metal pollutants into the bottom of the bed which can be a problem (Sekaran et al. 2007). There have also been attempts at phytoremediation of tannery waste to remove toxic pollutants (Gupta and Sinha 2006). Limited amounts of solid waste have also been used for the manufacture of glue (Hanna 2011).

In a country like Bangladesh, the huge amount of solid tannery waste has been traditionally disposed off through landfills. Most of these landfills were not constructed properly and therefore toxic metals, especially chromium, have leached out into the adjacent soil making it unfit for cultivation and other uses (Alvarez-Bernal et al. 2006).. Poultry and fish feed manufacturers have discovered the potential of these wastes to be the principal component of animal feed because of their protein content (Hossain et al. 2007). Solid tannery waste contains untanned components like raw trimmings and fleshings, which are mostly protein contaminated with some salts (Lofrano et al. 2013). The tanned component of the solid tannery waste comprises of splits, shavings and crusts and they contain a significant amount of inorganic materials in addition to the proteinous organic compounds (Lofrano et al. 2013). To use the solid waste in poultry feed, fish feed and fertilizers, both the groups of components are boiled for a few hours and then sun-dried. The dried material is then ground, producing what is called protein-concentrate (Hossain et al. 2007). When the idea of using this proteinconcentrate as animal feed was put into practice, the result was highly encouraging, as the chicks grew quite rapidly with these feeds (Paul et al. 2013). This is a perfect example of industrial symbiosis, an association between companies in which the wastes or byproducts of one become the raw materials for another (Chertow 2000; Hu et al. 2011). The tannery owners could now earn money by selling their wastes instead of spending money on land filling (Alam 2010). Owners could sell around 5 tons of tannery waste every day and the demand for this tannery waste is so high that a feed factory is ready to make an advance payment to ensure its annual supply of this proteinous waste (Alam 2010). However, the question of the toxicity of this waste and possible transfer to common food items like chicken, eggs and fish arose quite strongly (Bari et al. 2015; Hossain et al. 2009; Hossain et al. 2007; Hossain and Hasan 2014; Islam et al. 2007; Mazumder et al. 2013; Parvin and Rahman 2014). The heavy metal concentrations of 18 samples of solid tannery waste at Hazaribagh collected from different spots and from different stages of production indicated that chromium was present in all the solid tannery waste samples in the highest quantity (a maximum of $3.2 \%$ of the solid tannery waste) followed by $\mathrm{Cd}$, $\mathrm{Pb}$, As and $\mathrm{Hg}$ in trace amounts in some samples (Hossain et al. 2007). Islam et. al. have measured the amounts of heavy metals including chromium in some of the widely used poultry feeds and chromium is found to be in the range of $0.09-5.79 \mathrm{ppm}$ (Islam et al. 2007). Bari et. al. measured the chromium content in different body parts of chickens and the values range from less than 0.10 to $2.44 \mathrm{ppm}$ indicating that the chromium is entering into the meat of the chicken, possibly because of the chromium in the feed (Bari et al. 2015). Another study was done where the chickens were fed commercially available poultry feed mixed with leather shaving dust and skin cut waste for a 1 or 2 month period (Hossain and Hasan 2014). The concentrations of chromium found in different body parts of such chickens were similar to those obtained by Bari et al. Total amount of chromium has also been measured in different egg samples and the chromium content in albumen and yolk varies from 1.05 to $2.72 \mathrm{ppm}$ (Hossain et al. 2009). It is important to note that all of these studies emphasized on the 
measurement of total chromium rather than in the form of $\mathrm{Cr}$ (III) or $\mathrm{Cr}$ (VI) which we feel is a serious drawback of these studies.

\section{Management Of Chromium In Animal Feed}

If the amounts of chromium consumed by humans were assumed to be in the $\mathrm{Cr}$ (III) form, would these pose any health threat? The answer depends on which value we choose as the safe limit for consumption as shown in Table 2.

Table 1: Summary of dose levels of $\mathrm{Cr}$ (III) and $\mathrm{Cr}$ (IV) approved by different agencies

\begin{tabular}{|l|l|l|}
\hline Chromium (III) Toxicity & & Source \\
\hline Concentration & Adequate daily dietary intake & National Research Council (USA) (FDA 1995) \\
\hline $50-220 \mu \mathrm{g} /$ day & Reference daily intake & $\begin{array}{l}\text { Food and Drug Administration DA (USA) } \\
\text { United Nations Environment Programme et al. } \\
2015)\end{array}$ \\
\hline $120 \mu \mathrm{g} /$ day & Maximum intake & $\begin{array}{l}\text { European Food Safety Authority (United } \\
\text { Nations Environment Programme et al. 2015) }\end{array}$ \\
\hline $10 \mathrm{mg} /$ day & Safe for consumption & $\begin{array}{l}\text { Expert Group on Vitamins and Minerals (UK) } \\
\text { (Additives and Nutrient Sources added to 2010) }\end{array}$ \\
\hline $1.5 \mathrm{mg} / \mathrm{kg}$ body weight & No Observed Adverse Effect Level (NOAEL) & $\begin{array}{l}\text { Environmental Protection Agency (USA) } \\
\text { (Grevatt 1998) }\end{array}$ \\
\hline Chromium (VI) Toxicity & \multicolumn{2}{|l|}{} \\
\hline Concentration & \multicolumn{2}{|l|}{ Source } \\
\hline $8.2 \mu \mathrm{g} /$ day & Maximum Allowable Dose Level (MADL) & $\begin{array}{l}\text { The Office of Environmental Health Hazard } \\
\text { Assessment (OEHHA 2010) }\end{array}$ \\
\hline $0.142 \mathrm{mg} / \mathrm{kg}$ body weight & No Observable Effect Level (NOEL) & (Murthy et al. 1996) \\
\hline
\end{tabular}

According to the National Research Council (NRC) of USA, the safe and adequate daily dietary intake (ESADDI) for chromium is 50-200 $\mu \mathrm{g} / \mathrm{day}$ (Allowances et al. 1980). The Food and Drug Administration (FDA) has selected a reference daily intake of $120 \mu \mathrm{g} / \mathrm{day}$, which is within the range set by NRC (FDA 1995). Recently, a Panel on Food Additives and Nutrient Sources constituted by the European Food Safety Authority has recommended a maximum $\mathrm{Cr}$ (III) intake of $250 \mu \mathrm{g}$ /day in agreement with the WHO recommendation (Additives and Nutrient Sources added to 2010; United Nations Environment Programme et al. 2015). The panel has considered the available literature on $\mathrm{Cr}(\mathrm{III})$ and come to the conclusion that it is not possible at the moment to decide on the Tolerable Upper Intake Level (UL) of Cr(III). The UK Expert Group on Vitamins and Minerals (EVM) is also in agreement with the US Food and Nutrition Board that overall there are insufficient data from human and animal studies to derive a safe upper level for chromium. However, EVM opines that about $0.15 \mathrm{mg} / \mathrm{kg}$ body weight/day equivalent to $10 \mathrm{mg} /$ person should have no adverse health effects (Additives and Nutrient Sources added to 2010). In an attempt to establish an Oral Reference Dose (RfD), which is an estimate of a daily exposure to the human population that is likely to be without an appreciable risk of deleterious effects during a lifetime, an expert group selected by EPA reviewed the existing literature on the subject (Grevatt 1998). They found the work of Ivankovic and Preussman (Ivankovic and Preussman 1975) most appropriate for development of the RfD. Ivankovic and Preussman fed groups of male and female rats at dietary levels of $0 \%$ to $5 \% \mathrm{Cr}_{2} \mathrm{O}_{3}$ in bread, 5 days/week for 90 days in one study and 840 days in another study. Toxicological parameters including serum protein, bilirubin, hematology, urinalysis, organ weights, and histopathology were measured. With the exception of reductions $(12 \%-37 \%)$ in absolute weights of the livers and spleens, no adverse effects could be detected (Ivankovic and Preussman 1975). The reviewers determined the NOAEL (NoObserved-Adverse-Effect-Level) based on this study, which turned out to be $1468 \mathrm{mg}$ of $\mathrm{Cr}$ (III) per $\mathrm{kg}$ of body weight per day. A 100-fold uncertainty factor and a 10-fold modifying factor were introduced to get the reference dose of $1.5 \mathrm{mg}$ per $\mathrm{kg}$ of body weight per day, which means that a $70 \mathrm{~kg}$ person should have no adverse effect with the consumption of $105 \mathrm{mg}$ of $\mathrm{Cr}(\mathrm{III})$ per day (Grevatt 1998). No carcinogenic effect has been observed with $\mathrm{Cr}$ (III) in any study (Additives and Nutrient Sources added to 2010).

Let us examine in some more detail whether the amounts of total chromium (assumed to be all in +3 state) found in different body parts of chicken fed on tannery-based poultry feed do pose any real threat to public health. The amount of chromium is different for different body parts. Usually it is the maximum in liver. Bari et al have measured chromium content in liver, gizzard, meat and skin of three varieties of chicken broiler, native and free-ranging (Bari et al. 2015). Average minimum and maximum values (in $\mathrm{mg} / \mathrm{kg}$ ) were $0.202 \& 0.780$ for broiler, $0.138 \& 0.440$ for native and $0.111 \& 1.400$ for free-ranging chickens. If we take the average of the maximum values only, it turns out to be $0.873 \mathrm{mg} / \mathrm{kg}$. A careful examination of the safe dose levels given in Table 2 for $\mathrm{Cr}(\mathrm{III})$ would reveal that consumers are quite safe even if they ingest as much as $1 \mathrm{~kg}$ of chicken per day according to the values given in row $4 \& 5$. We presume that the values in row $1,2 \& 3$ are meant for adequate dietary intake, as $\mathrm{Cr}(\mathrm{III})$ is essential for health. Even then, with the value of $250 \mu \mathrm{g} / \mathrm{day}$ as 
recommended by the European Food Safety Authority, a person should have no problem if he does not consume more than $285 \mathrm{~g}$ of chicken per day. In view of the fact that chicken meat which constitutes the maximum proportion of edible chicken contains less than this amount $(0.873 \mathrm{mg})$ of chromium, it can be reasonably concluded that consumption of chicken containing only $\mathrm{Cr}(\mathrm{III})$ should not be of particular concern to public health. Similar conclusion can be drawn for chromium contamination in fish based on a recent study looking at chromium levels in fish and fish feed (Hasan et al. 2016). A question may be raised as to whether $\mathrm{Cr}$ (III) will be oxidized to $\mathrm{Cr}(\mathrm{VI})$ while cooking. The answer should be sought by doing experiments. However it is known that $\mathrm{Cr}(\mathrm{III})$ exists in aqueous solution as $\left[\mathrm{Cr}\left(\mathrm{H}_{2} \mathrm{O}\right)_{6}\right]^{3+}$ which is acidic and that chicken contains some reducing species. In the presence of reducing species and under acidic conditions there is little chance of $\mathrm{Cr}(\mathrm{III})$ being oxidized to $\mathrm{Cr}(\mathrm{VI})$; rather the contrary reaction of transformation of $\mathrm{Cr}(\mathrm{VI})$ to $\mathrm{Cr}(\mathrm{III})$ is more likely.

Unfortunately not much work has been done on the presence of $\mathrm{Cr}(\mathrm{VI})$ in food items of Bangladesh. By using spectrophotometric method involving diphenylcarbazide, Mazumder et. al. has recently looked at $\mathrm{Cr}(\mathrm{VI})$ in the protein concentrate and in chickens of Dhaka, Bangladesh and the maximum value of chromium in the chicken was $177 \mu \mathrm{g} / \mathrm{kg}$ in the liver (Mazumder et al. 2013). This work was further extended by Parvin and Rahman who collected chickens from almost all over the country and analyzed different body parts such as liver, gizzard, flesh and brain (Parvin and Rahman 2014). In order to check whether the amount of $\mathrm{Cr}(\mathrm{VI})$ increases with the age of the chicken, they collected chickens that were much older than those used for the previous study, ranging from 4 to 24 months. The amounts of $\mathrm{Cr}(\mathrm{VI})$ were also found to be much higher; the maximum value of $13 \mathrm{ppm}$ was obtained for the liver of a 2 year old chicken. Like Mazumder et al they also used the spectrophotometric method for the analysis of most of the samples. In order to be sure about the reliability of the method some samples were run through ion chromatography. $\mathrm{Cr}(\mathrm{VI})$ was found in albumen and yolk of eggs by both the methods. Extracellular fluids are believed to reduce most of the $\mathrm{Cr}(\mathrm{VI})$ to $\mathrm{Cr}(\mathrm{III})$ before they reach the site of absorption (Kerger et al. 1996). The small remnants of $\mathrm{Cr}(\mathrm{VI})$ may perhaps bioaccumulate otherwise such high amounts would not have been obtained for older chickens.

Following the publications of Islam et al, (2007), Hossain et al, (2007 \& 2009) and Hossain \& Hasan (2014), local newspapers of Bangladesh made headlines about the ill effects of the consumption of chicken containing large amount of chromium that has come through chrome tanning (Alam 2010). The newspapers recommended not using tannery waste at all for the manufacture of feeds and in fact the law-enforcing authorities went to the extent of destroying some of these feed factories (IRIN ; Star). Recently, the Bangladesh

Supreme Court has banned the use of solid tannery waste in the production of poultry feed (Shaon 2016).

Generally, $1 \mathrm{~kg}$ of poultry feed is composed of $600 \mathrm{~g}$ of meat bones and $400 \mathrm{~g}$ of other ingredients like soya oil cake, ground rice and dry fish (Alam et al. 2010). This $400 \mathrm{~g}$ of other ingredients should contain little or no chromium. The meat bone part can be divided into untanned and tanned waste. The untanned waste comprising of raw trimmings and fleshings, which constitutes $66 \%$ of the solid waste should again contain little or no chromium. It is this $34 \%$ of the solid waste (around $20 \%$ of the poultry feed), composed of split, shavings and crust of finished leather that contains chromium if the leather is made through chrome tanning. In order to be able to use solid tannery waste for the production of animal feed that would not cause harm to human health, the amount of chromium especially the hexavalent form should be present in the feed in as little quantity as possible. Chrome tanning being the most popular form of tanning, it would be almost impossible to completely get rid of chromium. Paul et. al. (Paul et al. 2013) have advocated the removal of chromium altogether from the solid waste before using it in the poultry feed. An oxidation method was used to achieve $95 \%$ removal of chromium from tannery solid waste and after further thermal and enzymatic treatment, the amount of $\mathrm{Cr}(\mathrm{VI})$ in the feed was low enough to be used. Whereas this is safer from the point of view of public health, the cost of production of poultry feed would go up significantly if their elaborate procedure for dechroming is followed. One way of reducing chromium would be to mix chrome leather with vegetable-tanned leather. Another approach to the problem is to change the ratio of different components in the feed so that chromium-containing leather part is at a minimum. The maximum allowable level for hexavalent chromium (as seen in Table 2) is 8.2 $\mu \mathrm{g} / \mathrm{day}$, which is more than 1000 times lower than the safe level of $\mathrm{Cr}(\mathrm{III})$ suggested by Expert Group on Vitamins and Minerals (Table 2). Thus from the point of view of public health, what is more important is the amount of hexavalent chromium present in feeds rather than trivalent chromium. To minimize the amount of $\mathrm{Cr}(\mathrm{VI})$ in the feed, one should look into the possible sources of $\mathrm{Cr}(\mathrm{VI})$. Amongst the direct sources, $\mathrm{Cr}(\mathrm{VI})$ contamination in $\mathrm{Cr}(\mathrm{III})$ tanning agent, certain class of metal complex dyes, and inorganic pigments based on lead chromate may be mentioned [29]. Apart from these direct sources which can be avoided, there are steps in the tanning process itself where $\mathrm{Cr}(\mathrm{III})$ is oxidized to $\mathrm{Cr}(\mathrm{VI})$. Devikavathi et. al. (Devikavathi et al. 2014) have used antioxidants like vitamin $\mathrm{C}$ and other natural biochemicals to arrest the conversion of $\mathrm{Cr}(\mathrm{III})$ to $\mathrm{Cr}(\mathrm{VI})$ at different stages of chrome tanning process (Devikavathi et al. 2014). They claim that by using a combination of antioxidants they have been able to obtain leather almost free from $\mathrm{Cr}(\mathrm{VI})$. Solid waste is boiled and then dried in the sun before using it as a component of poultry/fish feed. Boiling favors oxidation of $\mathrm{Cr}$ (III) to $\mathrm{Cr}(\mathrm{VI})$ and 
ultraviolet radiation from the sun is quite effective in causing the oxidation (Başaran et al. 2008). It is not surprising, therefore, that Mazumder et. al. have found more $\mathrm{Cr}(\mathrm{VI})$ in the boiled and dried solid waste than in the original solid waste (Mazumder et al. 2013). We believe it is possible to control the formation of $\mathrm{Cr}(\mathrm{VI})$ in these steps too. Boiling and drying which are essential for preventing putrefaction can be limited to untanned part (fleshings and trimmings) alone. Because this part is chromium free, the question of oxidation does not arise. The tanned part has already been made durable through tanning, so no further boiling is necessary. This would save both time and money. The two parts can be ground together to be used in the animal feed. It has been found that storage conditions also promote oxidation through formation of free radicals (Devikavathi et al. 2014). Solid tannery waste should thus be used as fresh as possible. By adopting these measures it should be possible to control the formation of $\mathrm{Cr}(\mathrm{VI})$ to a great extent so that the poultry feed and the poultry become no more concern for public health. Naturally the adoption of this management approach would push the cost of poultry feed up a bit but not as much as the other methods.

\section{Conclusion}

Land filling the enormous solid tannery waste that is generated by the tannery industry is not an acceptable option. The high protein content of this waste should somehow be utilized. Two alternative approaches have been discussed here. The alternative authored by Paul et. al. (Talbot and Chegwidden 1983) proposes to get rid of total chromium from the solid waste and the other, by the present authors, puts more emphasis on the prevention of formation of $\mathrm{Cr}(\mathrm{VI})$ taking effective measures at different stages of production of leather and poultry feeds, assuming that the amount of $\mathrm{Cr}(\mathrm{III})$ present would be harmless. More research is needed to find out which alternative is more convenient and less expensive. In either case the price of poultry feed will go up with concomitant increase in the price of chicken and eggs. Cooperation of all the stake holders including tannery owners, feed producers, poultry farmers and consumers will be needed in the greater interest of survival and flourishing of our tannery industries. This approach of utilizing the solid tannery waste is also in conformity with the modern concept of industrial symbiosis (Bain et al. 2010).

\section{References}

[1]. Additives EPoF, Nutrient Sources added to F (2010) Scientific Opinion on the safety of trivalent chromium as a nutrient added for nutritional purposes to foodstuffs for particular nutritional uses and foods intended for the general population (including food supplements) EFSA Journal 8:1882 doi:10.2903/j.efsa.2010.1882

[2]. Ahmed K, Das M, Islam MM, Akter MS, Islam S, Al-Mansur MA (2011) Physico-chemical properties of tannery and textile effluents and surface water of River Buriganga and Karnatoli, Bangladesh World Appl Sci J 12:152-159

[3]. Alam H (2010) Toxic poultry feed poses health risk. The Daily Star, Dhaka

[4]. Alam J, Hossain M, Beg AH, Nam K-C, Lee S-S (2010) Effects of Tannery Wastes on the Fattening of Growing Cattle, Carcass, and Meat Quality Korean Journal for Food Science of Animal Resources 30:190-197

[5]. Alibardi L, Cossu R (2016) Pre-treatment of tannery sludge for sustainable landfilling Waste Manag 52:202-211 doi:10.1016/j.wasman.2016.04.008

[6]. Allowances NRCCoD, Food NRC, Board N (1980) Recommended dietary allowances vol 2941. National Academies,

[7]. Alvarez-Bernal D, Contreras-Ramos S, Trujillo-Tapia N, Olalde-Portugal V, Frías-Hernández J, Dendooven L (2006) Effects of tanneries wastewater on chemical and biological soil characteristics Applied Soil Ecology 33:269-277

[8]. Assem L, Zhu H (2007) Chromium. Toxicological overview Health Protection Agency UK 14

[9]. Avudainayagam S, Megharaj M, Owens G, Kookana RS, Chittleborough D, Naidu R (2003) Chemistry of chromium in soils with emphasis on tannery waste sites. In: Reviews of Environmental Contamination and Toxicology. Springer, pp 53-91

[10]. Bain A, Shenoy M, Ashton W, Chertow M (2010) Industrial symbiosis and waste recovery in an Indian industrial area Resources, Conservation and Recycling 54:1278-1287

[11]. Bari ML, Simol HA, Khandoker N, Begum R, Sultana UN (2015) Potential Human Health Risks of Tannery Waste-contaminated Poultry Feed Journal of Health and Pollution 5:68-77

[12]. Barrett J, Brien P, De Jesus JP (1985) Chromium (III) and the glucose tolerance factor Polyhedron 4:1-14

[13]. Başaran B, Ulaş M, Bitlisli BO, Aslan A (2008) Distribution of Cr (III) and Cr (VI) in chrome tanned leather Indian Journal of Chemical Technology 15:511-514

[14]. bdnews24.com (2016) Tanneries Defy Relocation Deadline To Spew Toxic Waste Water, Police Move In To Cut Hide Supply. http://bdnews24.com/business/2016/04/01/tanneries-defy-relocation-deadline-to-spew-toxic-waste-water-police-move-in-to-cuthide-supply. Accessed 01/08/2016 2016

[15]. Benazir JF, Suganthi R, Rajvel D, Pooja MP, Mathithumilan B (2010) Bioremediation of chromium in tannery effluent by microbial consortia African journal of biotechnology 9:3140-3143

[16]. Bhuiyan MA, Suruvi NI, Dampare SB, Islam MA, Quraishi SB, Ganyaglo S, Suzuki S (2011) Investigation of the possible sources of heavy metal contamination in lagoon and canal water in the tannery industrial area in Dhaka, Bangladesh Environmental monitoring and assessment 175:633-649 doi:10.1007/s10661-010-1557-6

[17]. Burbridge DJ, Koch I, Zhang J, Reimer KJ (2012) Chromium speciation in river sediment pore water contaminated by tannery effluent Chemosphere 89:838-843 doi:10.1016/j.chemosphere.2012.05.005

[18]. Chertow MR (2000) Industrial symbiosis: literature and taxonomy Annual review of energy and the environment 25:313-337

[19]. Cheung K, Gu J-D (2007) Mechanism of hexavalent chromium detoxification by microorganisms and bioremediation application potential: a review International Biodeterioration \& Biodegradation 59:8-15

[20]. Chuan MC, Liu JC (1996) Release behavior of chromium from tannery sludge Water research 30:932-938 doi:10.1016/00431354(95)00227-8

[21]. Costa M (1997) Toxicity and carcinogenicity of $\mathrm{Cr}(\mathrm{VI})$ in animal models and humans Crit Rev Toxicol 27:431-442 doi:10.3109/10408449709078442 
[22]. Das AP, Singh S (2011) Occupational health assessment of chromite toxicity among Indian miners Indian journal of occupational and environmental medicine 15:6

[23]. De Flora S, Camoirano A, Bagnasco M, Bennicelli C, Corbett G, Kerger B (1997) Estimates of the chromium (VI) reducing capacity in human body compartments as a mechanism for attenuating its potential toxicity and carcinogenicity Carcinogenesis 18:531-537

[24]. Devikavathi G, Suresh S, Rose C, Muralidharan C (2014) Prevention of carcinogenic Cr (VI) formation in leather-A three pronged approach for leather products Indian Journal of Chemical Technology 21:7-13

[25]. Dhal B, Thatoi H, Das N, Pandey B (2013) Chemical and microbial remediation of hexavalent chromium from contaminated soil and mining/metallurgical solid waste: a review Journal of hazardous materials 250:272-291

[26]. Durai G, Rajasimman M (2011) Biological Treatment of Tannery Wastewater- A Review Journal of Environmental science and Technology 4:1-17

[27]. Famielec S, Wieczorek-Ciurowa K (2011) Waste from leather industry. Threats to the environment Czasopismo Techniczne Chemia 108:43-48

[28]. FDA (1995) Food labeling: reference daily intakes, final rule vol 60. USA

[29]. Futurestartup.com (2016) 17 Facts You Should Know About Bangladesh Leather Industry - Future Startup. Futurestartup. http://futurestartup.com/2015/08/23/17-facts-you-should-know-about-bangladesh-leather-industry/\#.V86e-TVuHIU. Accessed $01 / 08 / 20162016$

[30]. Ghosh S, Mukherjee S, Al-Hamdan AZ, Reddy KR (2012) Efficacy of Fine-Grained Soil as Landfill Liner Material for Containment of Chrome Tannery Sludge Geotechnical and Geological Engineering 31:493-500 doi:10.1007/s10706-012-9601-7

[31]. Goyer RA, Clarkson TW (1996) Toxic effects of metals Casarett \& Doull's Toxicology The Basic Science of Poisons, Fifth Edition, Klaassen, CD [Ed] McGraw-Hill Health Professions Division, ISBN 71054766

[32]. Grevatt P (1998) Toxicological review of trivalent chromium Integrated Risk Information System (IRIS), US Environmental Protection Agency, Washington, DC

[33]. Gupta AK, Ganjewala D, Goel N, Khurana N, Ghosh S, Saxena A (2014) Bioremediation of tannery chromium: A microbial approach Research Journal of Pharmacy and Technology 7:118-122

[34]. Gupta AK, Sinha S (2006) Chemical fractionation and heavy metal accumulation in the plant of Sesamum indicum (L.) var. T55 grown on soil amended with tannery sludge: Selection of single extractants Chemosphere 64:161-173 doi:10.1016/j.chemosphere.2005.10.016

[35]. Hanna B (2011) DETERMINATION OF OPTIMUM CONDITION FOR THE PRODUCTION OF COMMERCIALLY VIABLE GLUE FROM TANNERY SOLID WASTE. aau

[36]. Hasan S, Rahman L, Chowdhury SA (2016) Prevalence of Chromium in Fish Feed and Commercially Cultivated Tilapia

[37]. Hossain AM, Islam MS, Rahman MM, Mamun MM, Kazi MAI, Elahi SF (2009) Assessment of tannery based chromium ecotoxicity through investigating regional bio-concentration in commercially produced chicken eggs and their physical properties Bangladesh Journal of Scientific and Industrial Research 44:11-30

[38]. Hossain AM, Monir T, Ul-Haque AR, Kazi MAI, Islam MS, Elahi SF (2007) Heavy metal concentration in tannery solid wastes used as poultry feed and the ecotoxicological consequences Bangladesh Journal of Scientific and industrial research 42:397-416

[39]. Hossain MA, Hasan Z (2014) EXCESS AMOUNT OF CHROMIUM TRANSPORT FROM TANNERY TO HUMAN BODY THROUGH POULTRY FEED IN BANGLADESH AND ITS CARCINOGENIC EFFECTS International Journal of Civil, Structural, Environmental and Infrastructure Engineering Research and Development (IJCSEIERD) 1:1-10

[40]. Hu J, Xiao Z, Zhou R, Deng W, Wang M, Ma S (2011) Ecological utilization of leather tannery waste with circular economy model Journal of Cleaner Production 19:221-228

[41]. IRIN Toxic poultry feed threatens Bangladesh's poor IRIN. http://www.irinnews.org/report/100160/toxic-poultry-feed-threatensbangladeshs-poor Accessed 01/08/2016 2016

[42]. Islam MS, Kazi MAI, Hossain MM, Ahsan MA, Hossain AM (2007) Propagation of heavy metals in poultry feed production in Bangladesh Bangladesh Journal of Scientific and Industrial Research 42:465-474

[43]. Ivankovic S, Preussman R (1975) Absence of toxic and carcinogenic effects after administration of high doses of chromic oxide pigment in subacute and long-term feeding experiments in rats Food and cosmetics toxicology 13:347-351

[44]. Kanagaraj J, Velappan K, Babu N, Sadulla S (2006) Solid wastes generation in the leather industry and its utilization for cleaner environment-A review Journal of Scientific \& Industrial Research 65:541-548

[45]. Kashem MA, Singh BR (1999) Heavy metal contamination of soil and vegetation in the vicinity of industries in Bangladesh Water, Air, \& Soil Pollution 115:347-361

[46]. Kerger BD, Paustenbach DJ, Corbett GE, Finley BL (1996) Absorption and elimination of trivalent and hexavalent chromium in humans following ingestion of a bolus dose in drinking water Toxicol Appl Pharmacol 141:145-158 doi:10.1006/taap.1996.0271

[47]. Lofrano G, Meric S, Zengin GE, Orhon D (2013) Chemical and biological treatment technologies for leather tannery chemicals and wastewaters: a review The Science of the total environment 461-462:265-281 doi:10.1016/j.scitotenv.2013.05.004

[48]. Lopez-Luna J, Gonzalez-Chavez M, Esparza-Garcia F, Rodriguez-Vazquez R (2009) Toxicity assessment of soil amended with tannery sludge, trivalent chromium and hexavalent chromium, using wheat, oat and sorghum plants Journal of hazardous materials 163:829-834

[49]. Marzan LW, Hossain M, Mina SA, Akter Y, Chowdhury AMA (2017) Isolation and biochemical characterization of heavy-metal resistant bacteria from tannery effluent in Chittagong city, Bangladesh: Bioremediation viewpoint The Egyptian Journal of Aquatic Research

[50]. Mazumder L, Hasan S, Rahman M (2013) Hexavalent chromium in tannery solid waste based poultry feed in Bangladesh and its transfer to food chain IOSR J Environ Sci, Toxicol Food Technol 3:44-51

[51]. Megharaj M, Avudainayagam S, Naidu R (2003) Toxicity of hexavalent chromium and its reduction by bacteria isolated from soil contaminated with tannery waste Curr Microbiol 47:51-54 doi:10.1007/s00284-002-3889-0

[52]. Mondaca MA, Campos V, Moraga R, Zaror CA (2002) Chromate reduction in Serratia marcescens isolated from tannery effluent and potential application for bioremediation of chromate pollution TheScientificWorldJournal 2:972-977 doi:10.1100/tsw.2002.154

[53]. Murthy RC, Junaid M, Saxena DK (1996) Ovarian dysfunction in mice following chromium (VI) exposure Toxicol Lett 89:147-154

[54]. OEHHA (2010) Proposition 65 Oral Maximum Dose Level (MADL) for Developmental and Reproductive Toxicity for Chromium (Hexavalent Compounds). Office of Environmental Health Hazard Assessment http://oehha.ca.gov/media/downloads/proposition65/chemicals/081210draftmadlchromvi.pdf. Accessed 01/08/2016 2016

[55]. Pappu A, Saxena M, Asolekar SR (2007) Solid wastes generation in India and their recycling potential in building materials Building and Environment 42:2311-2320

[56]. Parvin S, Rahman ML (2014) Hexavalent chromium in chicken and eggs of Bangladesh Int J Sci Eng Res [Internet] 5:1090-1098 
[57]. Paul H, Antunes APM, Covington AD, Evans P, Phillips PS Towards zero solid waste: utilising tannery waste as a protein source for poultry feed. In: The 28th International Conference on Solid Waste Technology and Management, Philadelphia 2013. The Journal of Solid Waste Technology and Management,

[58]. Ping T, Youcai Z, Fengyi X (2008) Thermal behaviors and heavy metal vaporization of phosphatized tannery sludge in incineration process Journal of environmental sciences 20:1146-1152

[59]. Popov V (2005) A new landfill system for cheaper landfill gas purification Renewable Energy 30:1021-1029

[60]. Price JL, Joseph JB (2000) Demand management - a basis for waste policy: a critical review of the applicability of the waste hierarchy in terms of achieving sustainable waste management Sustainable Development 8:96-105 doi:10.1002/(sici)10991719(200005)8:2<96::aid-sd133>3.0.co; 2 -j

[61]. Program NT, Health UDo, Services H (2011) 13th Report on Carcinogens. June,

[62]. Rabbani KA, Charles W, Cord-Ruwisch R, Ho G (2015) Recovery of sulphur from contaminated air in wastewater treatment plants by biofiltration: a critical review Reviews in Environmental Science and Bio/Technology 14:523-534 doi:10.1007/s11157-0159367-5

[63]. Randall JA, Gibson RS (1987) Serum and Urine Chromium as Indices of Chromium Status in Tannery Workers Experimental Biology and Medicine 185:16-23 doi:10.3181/00379727-185-42510

[64]. Sallam AS, Usman AR, Al-Makrami HA, Al-Wabel MI, Al-Omran A (2015) Environmental assessment of tannery wastes in relation to dumpsite soil: a case study from Riyadh, Saudi Arabia Arabian Journal of Geosciences 8:11019-11029

[65]. Sekaran G, Swarnalatha S, Srinivasulu T (2007) Solid waste management in leather sector Journal on Design and Manufacturing Technologies 1:47-52

[66]. Shaon AI (2016) SC: Shut down plants using tannery waste in animal feeds. Dhaka Tribune, Dhaka

[67]. Sharif MI, Mainuddin K (2003) Country case study on environmental requirements for leather and footwear export from Bangladesh Dhaka: Bangladesh Centre for Advanced Studies

[68]. Sinha S, Gupta A, Bhatt K, Pandey K, Rai U, Singh K (2006) Distribution of metals in the edible plants grown at Jajmau, Kanpur (India) receiving treated tannery wastewater: relation with physico-chemical properties of the soil Environmental monitoring and assessment 115:1-22

[69]. Smoke T, Smoking I (2004) IARC monographs on the evaluation of carcinogenic risks to humans IARC, Lyon:1-1452

[70]. Star TD Four factories busted for using tannery waste The Daily Star http://www.thedailystar.net/four-factories-busted-for-usingtannery-waste-34792 Accessed 01/08/2016 2016

[71]. Talbot V, Chegwidden A (1983) Heavy metals in the sediments of Cockburn Sound, Western Australia, and its surrounding areas Environmental Pollution Series B, Chemical and Physical 5:187-205

[72]. UNIDO (2010) Future Trends in the World Leather and Leather Products Industry and Trade. United Nations Industrial Development Organization, Vienna

[73]. United Nations Environment Programme, International Labour Organisation, Organization WH (2015) Environmental Health Criteria for Chromium. http://www.inchem.org/documents/ehc/ehc/ehc61.htm. Accessed 01/08/2016 2016

[74]. WorstPolluted.org (2016) Top Ten Toxic Threats in 2013 WorstPolluted.org. www.worstpolluted.org/projects_reports/display/111. Accessed 01/08/2016 01/08/2016 